УДК: 81’23(075.8)

\title{
THE ROLE OF PSYCHOLOGY IN TEACHING FOREIGN LANGUAGES
}

\author{
I. G. Chebotarova \\ Kyiv, National Technical University of Ukraine \\ "Kyiv Polytechnic Institute" \\ innach777@mail.ru
}

\begin{abstract}
The article deals with psychological aspects in the process of foreign language mastering. It studies the role of Psychology in education and its relationship with Pedagogy and Linguistics. The article presents some historical facts of applying psychological theories in foreign language teaching underlining the importance of a teacher's professional language competence, factors of accounting of educational subject particularities and individual peculiarities of learners, especially motivation in learning foreign languages. This article gives psychological and pedagogical analysis of education with the main factors and components. The paper presents the definition of Pedagogical psychology, its close relationship with developmental and age psychology. The author defines the main parts of Pedagogical psychology and shows the significance of Educational psychology in the teaching process and its role in the foreign language mastering. The article gives its interrelation with other disciplines. The author underlines the significance of theories of human development for educational psychology and analyzes the main stages in the organization of work of every teacher. The role of two main aspects in the process of teaching - teaching and educating that are closely interconnected is considered. The paper presents the characteristic of the stages in the process of improving the intelligence of teaching.

Key words: foreign language, Psychology, Linguistics, teaching approaches and principles, professional language competence, motivation in learning, individual peculiarities, Pedagogical psychology.
\end{abstract}

Introduction. It is difficult to overestimate the meaning of a foreign language for modern society as it influences directly all the main life aspects in the development of every country. Nowadays, to be a highly qualified specialist signifies not only to be professional in your narrow sphere of knowledge but to master foreign languages as well. There exist different factors in providing successful foreign language teaching. One of the most important among them belongs to Psychology. Deep understanding of various psychological aspects may help teachers to solve many key moments in their work: to find a proper method of working in every students' group; to realize the right approach to students according to their skills and abilities taking into account complicated age peculiarities; to provide high motivation in foreign language mastering; to overcome natural problems, so called "barriers" appearing in the process of language studying.

For getting good knowledge of any language, either foreign or native, everybody should be acquainted with Psychology - the discipline that is closely connected with language teaching. According to the studied literature, many prominent scientists were interested in psychological side of Pedagogy trying to make the process of education more effective. Thus, J. Manesca, H. G. Ollendorff, H. Sweet, H. Palmer tried to apply psychological theories in their language teaching principles and approaches. I. V. Rahmanov was one of the leading researchers in the history of methods of teaching foreign languages. Much was done in this direction by 
S. Hardjono and H. Clark. Taking into account the importance of this theme for Pedagogy and the process of education, we want to determine the goal of this work.

The aim of this article is to study and analyze the role of Psychology in the process of teaching and learning foreign languages and to give justification of the necessity of psychological aspects application in the effective language teaching.

The meaning of Psycholinguistics. Nowadays, our modern society has realized the great need in foreign languages mastering as it opens new wide perspectives for a highly qualified specialist, makes higher his competitiveness, expands his outlook in all spheres of life presenting various foreign sources of information necessary for professional activity. A great help in the process of easy and effective learning a foreign language may be due to the knowledge of psychological principles.

First of all, we would like to start from the notion psycholinguistics - the Psychology of language. As it implies, psycholinguistics has its roots in two disciplines - Linguistics and Psychology. According to H. Clark, psycholinguistics is the study of three mental processes - the study of listening, speaking and the acquisition of these two skills by children. T. Harley expresses the same opinion that H. Clark considering psycholinguistics as the name given to the study of the psychology processes involved in language understanding, producing, and remembering language [1].

As it can be seen from these definitions, there exists a sort of relationship between Psychology, Linguistics and Pedagogy.

The history of foreign language teaching. Returning back to the history of foreign language teaching we want to notice that it is as old as the history of humanity. The need to learn foreign languages started from Latin as this language was the dominant one for education, commerce, religion during many centuries. Later it was displaced by other languages like French, Italian and English. Among those researchers who tried to reverse this process was J. A. Comenius. He composed the full course for Latin learning and was one of the theorists who examined languages learning laws. According to J. A. Comenius, teaching must be oral.

Modern languages study turned out not to be in the curriculum of schools in Europe until the 18th century. In accordance with the completely academic study of Latin, students of modern languages studied most of all grammatical rules and translated abstract sentences. The teaching seemed not to be oral at that time.

The rapid development of foreign language teaching began in the 19th century bringing different innovations in the 20th century which sometimes led to a number of conflicting methods, each trying to be a major improvement over the existed methods. The earliest linguists including H. G. Ollendorff (1803-1865), H. Sweet (1845-1912), O. Jespersen (1860-1943), and H. Palmer (1877-1949) tried to use linguistic and psychological theories in language teaching principles and approaches but many of the specific practical details were left by them for other researchers to devise.

The history of teaching foreign languages knows different methods that excluded and added each other. However, the principle about ambiguity, difficulty and spottiness of this process formulated by great didactics J. A. Comenius and 
I. G. Pestalocij is actual till nowadays. A. Disterverg considered the learner as the subject of education process, the educational subject being put on the second place.

All researchers who study foreign languages teaching are convinced that in this process the importance of a teacher's professional language competence, factors of accounting of educational subject particularities and individual peculiarities of learners, especially motivation in learning foreign languages are equal. According to these scientists, there are three equal components in the process of teaching foreign languages: a teacher and his professional skills; a learner and his aspiration; the subject which the learner must acquire.

It is absolutely normal that in psychological and pedagogical analysis of education we must consider components mentioned above. From our point of view the important factors and components of educational system are - psychological particularities of foreign language teachers; psychological peculiarities of learners of various age stages; psychological features of foreign language as an educational subject; psychological analysis of speech activity as an object of mastering; student's educational activity in the process of learning foreign languages and the form of education [2].

In continuation of our discussion of significant factors successfully influencing foreign language mastering we would like to mention a close connection of psychology of foreign language teaching with pedagogical psychology as one of the most important branch of Psychology. It studies mostly psychological aspects of concrete activity of teaching and learning.

The role of Pedagogical psychology in the educational process. Pedagogical psychology is closely connected with developmental and age psychology, which study age dynamics of person's mental development, ontogenesis of mental process and psychological quality of developing person. Ontogenesis refers to the sequence of events involved in the development of an individual organism from its birth to its death. This developmental history often involves a move from simplicity to higher complexity. So, all problems of development and age psychology are considered on the basis of accounting person's age features. Pedagogical and age psychology in their researching are based on the theories of General Psychology, which opens the general psychological laws, studies mental processes, mental conditions and person's individual and psychological peculiarities [2].

Pedagogical psychology became an independent branch at the end of 19th century when a lot of experiments and achievements in Pedagogy and Psychology were made. It consists of Educational Psychology, Upbringing Psychology and Teacher's Psychology. This field of psychology is often called Educational Psychology in America.

Educational psychology is the study of how humans learn in educational settings, the effectiveness of educational interventions, the psychology of teaching, and the social psychology of schools as organizations. Educational psychology is concerned with how students learn and develop, often focusing on subgroups such as gifted children and those who have specific disabilities [2].

To understand deeper Educational psychology it's better to examine properly its interrelation with other disciplines. Most information is sure to come from Psychology though in its turn it enriches many other branches of science. Educational 
psychology both takes from and contributes to cognitive science and the learning sciences.

We consider that for better understanding of student abilities every teacher should be acquainted with his distinguishing features, individuality not only in adulthood but in his childhood as well. For this purpose educational psychology develops and applies theories of human development. They are rather important here as their main goal is to examine all the changes in mental abilities, moral reasoning about the nature of knowledge.

Organization of a teaching process. Organizing the teaching process, a teacher should apply the educational principle, paying attention to psychological aspects of teaching and adapting the material and method of teaching to the physical development of learners.

S. Hardjono [1] came to the conclusion that in the organization of the work and especially in conveying the material a teacher should trade on:

1) general psychology theory;

2) psychology of developing level age;

3) typology of many psychological development levels;

4) psychology of individual characteristic.

There are two main aspects in the process of teaching - teaching and educating that are closely interconnected. The aim of educating is to develop a personality of a student. Teaching must give more knowledge, improving student's skills and abilities. For the successful teaching and educating process a teacher should understand properly the stage of a student's developing of both these two aspects to advance him in his mastering a foreign language. This should be taken into account in the choice of approaches during the work, in the selection of exercises, texts.

S. Hardjono pays much attention to the process of improving the intelligence of teaching. He divides it into four stages:

1) teacher presents and explains the new material;

2) teacher convinces that the new material has really been mastered by the learners;

3) teacher trains learners in order that they are able to produce the material by themselves;

4) teacher educates learners, so that they are able to use the material actively and creatively [1].

The next step in the successful process of a language mastering belongs to students' attention. For better presenting the material and absorbing it by students as well a teacher should be acquainted with psychological theory that is connected with the process of directing attention and process of absorbing the material of a given lesson. Besides, it's also very important for every teacher to concentrate students' attention. For this purpose a teacher uses various teaching techniques.

Thus, the use of visual aid at exact time is a great help in this case. A teacher should care about it not to lose students' attention after a few minutes. It's very essential to use visual aid at exact time otherwise the effect will be quite opposite. For example, a picture or some table hanging in front of a class at the beginning of a lesson will not give a positive effect as students have already seen it and their 
attention will not be concentrated on it at a proper moment. In this case the use of visual aid not at exact time will give more likely negative effect.

We also want to mention the dependence of students' attention on the interest to the studied material. The aim of every teacher is to rise up the interest to the presented material. Psychological knowledge will help here as for rising students' interest up a teacher needs to know the condition of learners' psychic before. The interest is sure may be caused by two factors: motivation to get knowledge and positive emotional attitude of something.

We have noticed that interest always appears with practical and effective activity and motivation of getting knowledge can appear if students understand the studied material and can be able to absorb it. Not less important factors in this process belongs to a teacher as a personality, his attitude and feelings to his students and the manner of presenting the material, his ability to find the best approach to the learners. Students may have great desire to learn a foreign language and to speak it fluently as quick as possible but their interest sometimes is very low because they do not see the results from what they study.

S. Hardjono believes that, comprehension that should be got by the learners is divided into two kinds: general comprehension and specific comprehension. If the learners only get the general comprehension, their knowledge will be superficial and, on the contrary, if the learners only get specific comprehension, they will get only some knowledge. For example: a teacher gives some difficult sentence of a foreign language. If a teacher gives its translation, the learners understand the sentence in general because they do not understand phrases, structures etc. On the contrary, if a teacher asks the learners to pay attention to specific things only, such as the meaning of words, using of grammar tense, etc, the learners will not understand the whole sentence. It means that a teacher should try to pay attention to both these comprehension presenting the material in order to give the opportunity for students of getting the result from what they study [1].

The last learner's experience plays an important role in comprehension of a new material.

Conclusions. From the research that has been carried out, it is possible to conclude that teaching foreign languages will be more effective if it is based not only on the basic principles of educational science but on application of the principles of psychological science as well because every kinds of teaching relates to mental aspects. The next stage of our work will be connected with the experimental confirmation of our research.

\section{REFERENCES}

1. Arif, N. (2012). The application of psychology in teaching foreign languages. Retrieved from http://journal.unbari.ac.id/index.php/JIP/article/view/74 [in English].

2. Kudysheva, A. A. (2010). Psychology of teaching foreign languages. Pavlodar, Russia: Kereku [in English].

\section{І. Г. Чеботарева. Роль психології в навчанні іноземних мов}

У статті розглядаються психологічні аспекти в процесі іншомовного засвоєння. Вивчається значимість психології для освіти та їі зв'язок з педагогікою і лінгвістикою. У статті представлені історичні факти застосування психологічних теорій в галузі викладання 
іноземної мови, при цьому виокремлюється важливість професійної мовної компетенції вчителя, фактори врахування особливостей навчального предмета та індивідуальні особливості учнів, особливо роль мотивації у вивченні іноземних мов. Ця стаття надає психолого-педагогічний аналіз освітнього процесу з основними факторами-компонентами. Тут дається визначення педагогічної психології, розглядається іiї тісний взаємозв'язок 3 розвиваючої та вікової психологією. Автор виділяє основні частини педагогічної психології. Обгрунтовується значимість педагогічної психології в процесі навчання, iї роль в іншомовному засвоєнні, а також іiі взаємозв'язок з іншими дисциплінами. У статті показана значимість теорій людського розвитку для педагогічної психології, аналізуються основні етапи в організації роботи кожного вчителя. Розглядається роль двох основних аспектів у процесі навчання - навчання і виховання, які тісно пов'язані між собою. Дана стаття надає характеристику етапів в процесі вдосконалення майстерності викладання. Автор дає аналіз основних етапів успішного засвоєння іноземної мови, розглядає поняття "осмислення" i визначає його значимість для навчального процесу, а також обгрунтовує важливість наявності високої мотивації до вивчення іноземних мов та необхідність ії підвищення в процесі вдосконалення мовної та мовленнєвої компетентності, а також прийняття до уваги попереднього мовного досвіду студентів.

Ключові слова: іноземна мова, психологія, лінгвістика, методи і принципи навчання, професійна мовна компетентність, мотивація в навчанні, індивідуальні особливості, педагогічна психологія.

\section{И. Г. Чеботарева. Роль психологии в обучении иностранным языкам}

В статье рассматриваются психологические аспекты в процессе иноязычного усвоения. Изучается значимость психологии для образовании и ее связь с педагогикой и лингвистикой. В статье представлены некоторые исторические факты применения психологических теорий в области преподавания иностранного языка, при этом акцент делается на важности профессиональной языковой компетенции учителя, факторах учета особенностей учебного предмета и индивидуальных особенностей учащихся, особенно мотивации в изучении иностранных языков. Эта статья предоставляет психологопедагогический анализ образовательного процесса с основными факторами-компонентами. Здесь дается определение педагогической психологии, ее тесной взаимосвязи с развивающей и возрастной психологией. Автор выделяет основные части педагогической психологии. Обосновывается значимость педагогической психологии в процессе обучения, ее роль в иноязычном усвоении, а также ее взаимосвязь с другими дисциплинами. В статье показана значимость теорий человеческого развития для педагогической психологии, анализируются основные этапы в организации работы каждого учителя.

Ключевые слова: иностранный язык, психология, лингвистика, методы и принципы обучения, профессиональная языковая компетентность, мотивация в обучении, индивидуальные особенности, педагогическая психология. 